\title{
To delete or not to delete: The contexts of Icelandic Final Vowel Deletion
}

\author{
Nicole Dehé ${ }^{\mathrm{a}, \mathrm{b}, *}$ \\ ${ }^{a}$ University College London, Department of Phonetics and Linguistics, United Kingdom \\ ${ }^{\mathrm{b}}$ Freie Universität Berlin, Department of English Language, Literature and Culture, Berlin, Germany
}

\begin{abstract}
Icelandic Final Vowel Deletion (FVD) is a phonological rule that deletes word-final unstressed vowels before initial vowels of the next word. To date, it has not been studied systematically. The research reported here is based on data from three different sources. The results show (i) that syntactic information is insufficient to fully account for the contexts of FVD application, (ii) that prosodic constituency plays a crucial role but fails to explain the full pattern because (iii) eurhythmy may affect phonological rule application at a higher level in the prosodic hierarchy, and (iv) that focus affects FVD application indirectly via its impact on prosodic phrasing.
\end{abstract}

Keywords: Icelandic; Vowel deletion; Prosodic phrasing; Rhythm; Focus

\section{Introduction}

This paper focuses on the distribution and governing factors of a segmental process in Icelandic which I will refer to as Final Vowel Deletion (FVD). The vowel inventory of Modern Icelandic is given in (1) (after Thráinsson, 1994; Árnason, 2005), where the letters of the alphabet representing vowels are followed by the respective IPA symbols indicating their phonetic quality.

* Present Address: Freie Universität Berlin, Department of English Language, Literature and Culture, Gosslerstr. 2-4, 14195 Berlin. Tel.: +49 3083872311 ; fax: +49 3083872323 .

E-mail address: ndehe@zedat.fu-berlin.de. 
(1) Modern Icelandic Vowel System ${ }^{1}$

a. monophthongs:

a [a], e [E], i/y [r], í/ý [i], o [o], u [Y], ú [u], ö [œ]

b. diphthongs:

á [au], ó [ou], æ [ai], ei/ey [عi], au [øy]

In Icelandic, word stress falls regularly on the first syllable (Árnason, 1985, 1987). This is true regardless of the number of syllables a word has and holds for compounds, too.

According to Einarsson (1973:27), “[u]nstressed vowels of endings are often elided before initial vowels of the next word". This seems in line with the general observation that languages seek to retain material of greater auditory salience rather than auditorily weaker material (cf. Casali, 1997:494, and references given there). In Icelandic, vowel sequences are resolved by deleting the weaker (unstressed) final vowel while retaining the stronger (stressed) vowel on the next word.

To the best of my knowledge, Icelandic FVD has not been systematically studied. The only examples Einarsson provides are given in (2) (all examples and phonetic transcriptions taken from Einarsson, 1973:27). (2)(a)-(c) illustrate the process using the auxiliary ertu ('are.you'). In (2)(a), the final vowel on ertu [ $\left.{ }^{\mid} \varepsilon_{0} \cdot t y\right]$ cannot be elided because it is followed by an onset consonant on búinn. In (2)(b) and (c), however, it is followed by a word-initial vowel and can thus be elided. Similarly, the final vowel of ekki cannot be elided in (2)(b) due to the onset consonant on búinn, but it can be elided in (2)(c) due to the adjacent initial vowel on enn. In (2)(d), the final vowel on ekki may be deleted due to the following er. (Target vowels are underlined throughout the paper.)

\begin{tabular}{|c|c|c|}
\hline a. & 'Ertu 'búinn? & [er $\cdot$ ty $\cdot$ busin $]$ \\
\hline b. & $\begin{array}{l}\text { are.you ready } \\
\mid \text { Ertu } \mid \text { ekki }\left.\right|_{\text {búinn? }}\end{array}$ & [Er.t $\varepsilon^{h} \mathrm{k}_{\mathrm{j}} \cdot \mathrm{I}$ builn $]$ \\
\hline c. & $\begin{array}{l}\text { are.you not ready } \\
\left.\left.\left.{ }_{\text {Ertu }}\right|_{\text {ekki }}\right|_{\text {enn }}\right|_{\text {búinn? }} \\
\text { are.you not yet ready }\end{array}$ & {$\left[\varepsilon_{0} \cdot t \varepsilon^{h} k_{j} \varepsilon n: b^{\prime} ı n\right]$} \\
\hline 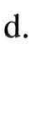 & $\begin{array}{l}\text { 'Ekki er að tala um bac } \\
\text { not is to talk about that } \\
\text { 'No need to discuss that' }\end{array}$ & 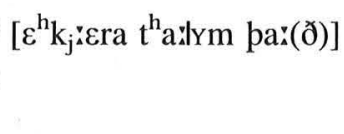 \\
\hline
\end{tabular}

However, not only functional elements such as the auxiliary ertu are subject to FVD. Rather, FVD also occurs on lexical elements such as verbs (illustrated by Einarsson's (2)(d): since tala precedes $u m$, its final vowel may be deleted), adjectives, adverbs, and nouns. The corresponding examples in (3) are taken from my own study. Also according to my data, the function of the syllable involved does not seem to play a role. The elidable vowel can be part of an inflectional suffix as in (3)(c) (stem borg 'city' + ACC Sg. def. -ina), or it can be part of the lexical stem as in níu in (3)(a). Furthermore, vowel deletion of this kind can also be observed before a weak pronoun beginning with $h$, as in (4). In (4)(a), the final vowel on sýndi is elided before a weak pronoun which behaves like an enclitic in many respects and whose initial $h$ is dropped. The resulting surface form is [sintonym]. The sequence in (4)(b) (provided by Kristján Árnason, personal communication) behaves correspondingly, resulting in the surface form [faknonym].

\footnotetext{
${ }^{1}$ The citation form of é is [je]. It is therefore not included in this list.
} 
(3) a. Siggi er níu ára.

Siggi is nine years

b. Hann valdi einn lykil.

$\mathrm{He}$ chose one key

c. Heðan sjáum við vel yfir borgina okkar.

From.here see we well over town-ACC.Sg.def our

'From here we have a good view over our town.'

d. Parna er Viðey.

There is Viðey

(4) a. Siggi kallaði á pabba og sýndi honum.

Siggi called for Dad and showed him

b. Ég fagna honum.

I receive.with.pleasure him/it

Note also that FVD does not affect all vowel types. It is attested with [I, a, $\mathrm{Y}, \mathrm{u}]$, but not $[\varepsilon, \supset, \propto]$. As Kristján Árnason (personal communication) points out, the set of vowels seems to be 'native, historically unstressed vowels', i.e., not final vowels in borrowings unless they belong to this set. In the present study, only the vowels for which deletion is attested have been included. ${ }^{2}$

In previous literature on other languages, it has often been argued that the context for the application of phonological rules, among them vowel deletion rules, can be defined by certain syntactic configurations or by the edges of prosodic constituents. For example, syntactic information has been held responsible for the application of vowel deletion rules in Greek (Kaisse, 1977, 1985), French liaison (Selkirk, 1974), Italian Raddopiamento Sintattico (Napoli and Nespor, 1979), and palatalisation and alveolar flapping in English (Cooper and Paccia-Cooper, 1980). All of these phenomena have been reanalysed as processes governed by prosodic rather than syntactic structure. Specifically, examples of rule application governed by prosodic constituent structure, most notably at Phonological Phrase level but also at Intonational Phrase and Utterance level, include the following ${ }^{3}$ : Greek vowel deletion rules (Nespor, 1987), French liaison (Nespor and Vogel, 1986), Italian Raddopiamento Sintattico (Nespor and Vogel, 1986; Ghini, 1993; among others), English flapping (Nespor and Vogel, 1986), Final Vowel Lengthening in Italian (e.g., Ghini, 1993), the distribution of vowel length in the Bantu languages ChiMwiini (Kisseberth and Abasheikh, 1974; Selkirk, 1986) and Chichewa (Kanerva, 1990), Obstruent Voicing in Korean (Cho, 1990), /r/ Assimilation and Voicing Assimilation in Bengali (Hayes and Lahiri, 1991), Welsh

\footnotetext{
${ }^{2}$ For examples of final vowels that do not undergo deletion, compare (i)(a) with (i)(b) and (i)(c) (examples from Kristján Árnason, personal communication).

(i) a. Ég fer til Kanada á morgun. $\rightarrow$ FVD applies

I go to Canada tomorrow

b. Ég fer til Umeåa á morgun.

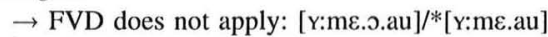

c. Ég fer til Malmö á morgun.

$\rightarrow$ FVD does not apply: [malmœ.au]/*[malmau]

A reviewer notes that this exclusion of more "marked" vowels connects the process described here to morphophonemic deletion of vowels in inflection. I believe that the relation between word level and phrase level phenomena deserves a separate study and goes beyond the scope and the aim of the present paper.

${ }^{3}$ The prosodic hierarchy assumed in this article follows much previous work on prosodic phonology (e.g., Nespor and Vogel, 1986; Selkirk, 1986, 1995; Truckenbrodt, 1995, 1999). The relevant levels of Utterance, Intonational Phrase, Phonological Phrase, Prosodic Word, Foot and Syllable are widely agreed on.
} 
Soft Mutation (Hannahs, 1996), and the resolution of stress clashes (Sandalo and Truckenbrodt, 2002, referring to Abousalh, 1997, for Brazilian Portuguese; Liberman and Prince, 1977, and Nespor and Vogel, 1986:177f. for English; Post, 1999 for French; Ghini, 1993, and Nespor and Vogel, 1986 for Standard Northern Italian; among many others).

Phonological rule application has also been shown to be affected by eurhythmy. In particular, as mentioned by Nespor (1987:66), "[s]ince the effect of [vowel deletion] is the deletion of a syllabic nucleus, it is typically a rule that alters the rhythmic pattern of a string". Across languages, both stress clashes and lapses tend to be avoided and processes apply to remedy undesired rhythmical patterns (Nespor and Vogel, 1989; among others). Accordingly, rhythmical constraints have been argued to affect, for example, the application of vowel degemination in Greek such that it cannot apply if it results in a stress clash (Nespor, 1987). By the same token, Kuijpers and Van Donselaar (1997) show that in Dutch, schwa deletion and schwa epenthesis are influenced by the rhythmical context. For European Portuguese, Frota (2000) establishes a relation between vowel deletion, eurhythmy and prosodic phrasing, such that non-deletion is preferred if deletion results in a stress clash within a Phonological Phrase. Like other languages, Icelandic seeks to avoid the adjacency of two stressed syllables (Kristján Árnason, personal communication), a tendency that has been considered to be universal (cf. among many others, Golston and Riad, 2000). Since Icelandic FVD results in the deletion of a weak syllable, it may yield a stress clash, or it may affect the rhythmical structure in another (desired or undesired) way. Accordingly, it may be enhanced or blocked in the interest of the overall rhythmical pattern.

Another factor that has been shown to affect phonological rule application is focus. In Korean, to give but one example, interrogative pronouns and words with narrow focus allow for voicing of initial consonants on the following word in contexts where in neutral declaratives voicing would be blocked (Cho, 1990).

In light of all this, a relation between the application of Icelandic FVD and syntactic and/or prosodic structure seems to suggest itself, as well as effects of focus and eurhythmy on FVD application. An analysis of Icelandic prosodic phrasing is not yet available, except for an analysis of boundary tones terminating Intonational Phrases (Árnason, 1998; cf. also Dehé, 2007). However, following prosodic theory (Nespor and Vogel, 1986; Selkirk, 1986, 1995 and related work; Truckenbrodt, 1995, 1999), we expect the right edges of Phonological Phrases in (abstract) prosodic structure to coincide with the right edges of XPs in syntactic structure.

The questions addressed in this paper are therefore the following. What are the syntactic environments in which FVD applies obligatorily or optionally and where is it blocked? What can be said about the relation between (abstract) prosodic phrasing and FVD application? And finally, do focus patterns and eurhythmy affect FVD application?

The hypotheses, which are based on much previous literature on related topics, are as follows.

(i) The stronger the syntactic boundary, the less likely FVD is to apply. We may conclude from the examples given above that FVD may apply within the VP (cf. (2)(d), (3)(b) and (4)), and within the NP (cf. (3)(a) and (3)(c)).

(ii) The stronger the prosodic boundary, the less likely FVD is to apply.

(iii) Eurhythmy may affect the application of FVD.

(iv) Focus may affect the application of FVD. ${ }^{4}$

\footnotetext{
${ }^{4}$ Since in other languages, focus may either soften the strength of a boundary (e.g., Cho, 1990 for Korean) or enhance it (e.g., Hayes and Lahiri, 1991 for Bengali; Kanerva, 1990 for Chichewa; Selkirk and Shen, 1990 for Shanghai Chinese; Selkirk, 2000), or not affect it at all (e.g., Frota, 2002 for European Portuguese), predictions in either direction are difficult to make for Icelandic at this stage.
} 
These hypotheses may lead to the same or to different predictions. For illustration, the examples in (5) through (7) compare the predictions made by hypotheses (i) (syntactic information) and (iii) (eurhythmy). In (5), syntax and eurhythmy make identical predictions, while in (6) and (7), predictions differ. In (6), syntax predicts vowel deletion while the rhythmic pattern predicts vowel retention, and vice versa in (7). Specifically, in (5), the target vowel sequence is in a syntactic context which predicts FVD blocking due to the NP boundary between the two vowels. Based on the rhythmical pattern, blocking of FVD is also predicted since its application would result in a stress clash. In (6), the target vowel (final -u on skoðuðu) is in the same VP as the following word, thus syntax predicts deletion. However, deletion would destroy the regular dactylic pattern, and eurhythmy thus predicts vowel retention. In (7), FVD is predicted to be blocked on the basis of the NP-boundary separating töskuna and um, while in the interest of lapse resolution, the final vowel of töskuna is likely to be deleted. (Here and below, the two grid levels represent the syllable and foot levels of the prosodic hierarchy.)

Syntax and eurhythmy predict blocking of FVD

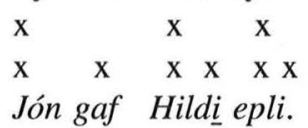

Jón gaf Hildi epli.

Jón gave Hilda an.apple

(6)

Syntax predicts FVD application, eurhythmy predicts blocking of FVD (regular dactyl)

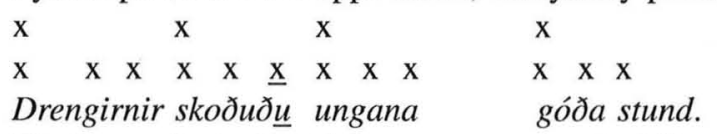

The.boys looked.at the.young.ones good.while

Syntax predicts FVD blocking, eurhythmy predicts FVD application (to arrive at regular dactyl)

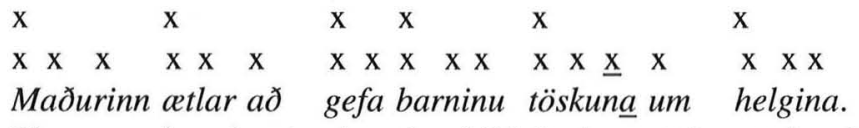

The.man is.going.to give the.child the.bag at.the.weekend

The hypotheses were tested on the basis of the following data sets. Firstly, a reading experiment was designed to test hypotheses (i) (syntax) and (iv) (focus). Secondly, data drawn from a recording of an Icelandic children's story read by a native speaker were used to shed light on hypotheses (i) (syntax) and (iii) (eurhythmy). And thirdly, the same speaker read a number of sentences designed to test hypothesis (iii) (eurhythmy). On the basis of the findings, conclusions regarding hypothesis (ii) (prosody) may also be drawn.

The results of the study provide evidence for the assumptions that it is prosodic structure rather than syntactic structure that affects FVD application, that focus does not directly affect FVD application but only indirectly such that focus affects prosodic phrasing which in turn affects FVD application, and that eurhythmy plays a crucial role in determining which vowel may go both across and within syntactic and prosodic boundaries. The results are in line with much recent work on phonological rule application in a number of other languages.

The paper is organised as follows. Section 2 gives an overview of the three data sources and the methodology. This is followed by an overview of the results in section 3 . Section 4 is a 
discussion of the results, taking into account the four hypotheses this study seeks to pursue. And finally, section 5 serves as a short conclusion.

\section{Data and method}

\subsection{The experimental study}

\subsubsection{Materials}

A reading experiment was designed primarily to address hypothesis (i) (the stronger the syntactic boundary, the less likely FVD is to apply). As far as abstract prosodic structure can be derived from syntactic structure, hypothesis (ii) (the stronger the prosodic boundary, the less likely FVD is to apply) can also be addressed on the basis of the experiment. Furthermore, hypothesis (iv) (focus may affect the application of FVD) was addressed by part but not all of the experimental materials. The target items were designed such that sequences of two immediately adjacent words $\mathrm{w} 1$ and $\mathrm{w} 2$, where $\mathrm{w} 1$ ended in an unstressed vowel and $\mathrm{w} 2$ started with a vowel, were embedded in carrier sentences in a number of different environments. Part of the materials was designed such that a syntactic clause boundary separated w1 and w2, part of them involved a syntactic XP-boundary, while part of them was designed such that w1 and w2 were within the same XP projection. According to hypothesis (i) above, FVD application should be least likely across a syntactic clause boundary, and most likely within a syntactic XP. For some target items, the focus structure was varied to test the effect of focus on FVD application.

Overall, 46 carrier sentences containing 47 target vowel sequences were constructed. (Examples are given in (8) through to (10); the full materials are given in Appendix A to this article. As above, all target vowels are underlined.) The experimental items were divided up in three groups. 2 carrier sentences ( 3 vowel sequences) belonged to Group 1 in which the target vowel sequences were separated by a clause boundary (cf. (8)). 38 items belonged to Group 2 involving an XP-boundary separating the target vowels (cf. (9)). And finally, Group 3 was made up of six target items in which the target vowel sequence was within one XP (cf. (10)). Due to the nature of the predictions and the syntactic make-up of the materials, the overwhelming majority of the data belonged to Group 2. Specifically, predictions were assumed to be safer at clause boundaries and within XPs than at XP boundaries. Moreover, it was my intention to test XP boundaries in different positions within a sentence. These positions are represented in the examples in (9): in (9)(a), the target vowel sequence is placed at the boundary between subject-NP and VP; in (9)(b), it is located between two nominal objects in a double object construction; in (9)(c), the relevant boundary is between the second of two nominal objects and a phrasal adjunct; in (9)(d), it is between a nominal object and a verbal particle. ${ }^{5}$ Note that within the subgroup involving an XP-boundary between subject and VP (cf. (9)(a)) the length of the subject was varied such that some items contained simple subjects (e.g., Jónína), while some contained more complex subjects (e.g., Birna og Jónína).

Focus patterns were varied in Group 3 and in a subset of Group 2. The six items in Group 3 were devided up into three neutral declaratives (cf. (10)(a)) and three items involving narrow verb focus (cf. (10)(b)). Within Group 2, 10 items were of the type (9)(a), i.e., the target vowel was

\footnotetext{
${ }^{5}$ In Icelandic, the verbal particle can be placed either between the two objects or following both objects, but it cannot precede both objects (e.g., Collins and Thráinsson, 1996:435ff). Accordingly, the particle was placed between the two objects in three items, and followed the two objects in another three items. The object preceding the particle ended in a vowel in all items, while all particles started with a vowel.
} 
subject-NP-final. 6 of these were presented twice in the course of each session: once as a neutral declarative (cf. (9)(a)), and again as a response to a wh-question focusing on the subject (cf. $\left.(9)\left(a^{\prime}\right)\right)$.

(8) Group 1: Target vowels separated by a clause boundary (FVD predicted to be blocked) Auður hjálpaði barninu, Anna hjálpaði konunni, Elísabet hjálpaði lakninum.

Auður helped the.child, Anna helped the.woman, Elisabeth helped the.doctor

(9) Group 2: Target vowels separated by an XP-boundary (4 different environments; FVD predicted to be blocked)
a. Subject-NP] [VP; neutral declarative Birna og Jónína elda ekki fisk. Birna and Jónína cook not fish
$\mathrm{a}^{\prime}$. Subject-NP] [VP; narrow subject focus (Hver eldar ekki fisk?)
b. V Object-NP] [Object-NP Kennslukonan gaf barninu orðabók. the.female.teacher gave the.child a.dictionary
c. Object-NP] [PP-adjunct Húseigandinn atlar að sýna konunni íbúðina um helgina.
d. Object-NP] [verbal particle Gísli sendi konunni (út) peningana (út).
Gísli sent the.woman Part-out the.money Part-out

(10) Group 3: Target vowels within one XP (here: [V NP]; FVD predicted to apply)
a. Neutral declarative
María borðaði appelsínuna
Mary ate the.orange
b. Verb focus
Q: Hvað gerði María við appelsínuna? ('What did Mary do with the orange?')
A: María [bordaði $]_{\text {Foc }}$ appelsínuna.

In addition to these items, another 59 items were part of the materials. These items, too, contained vowel sequences in various positions but they were very heterogeneous in nature and were not designed following any experimental hypothesis. They were thus not included in the analysis and can be considered filler items for the purpose of the present study. Moreover, all words that were first in their target sequences (e.g., barninu, konunni, Jónína, íbúðina, borðaði) were also presented individually in order to allow for comparisons between their citation forms and the forms pronounced in their respective target positions.

The acceptability of all experimental items was checked by two native speakers of Icelandic. In the experimental design, the items (target items, filler items, and individual words) were pseudo-randomised such that two items of the same group were not allowed in a sequence. 


\subsubsection{Participants, apparatus and procedure}

The experiment was conducted with 12 untrained, unpaid participants ( 1 male, 11 female) at the University of Iceland in Reykjavík. All participants were students at the university. They were native speakers of Icelandic in their early twenties and were naïve as to the aim of the study.

All participants were tested individually in a quiet, closed room. The target utterances were presented to them individually on a computer screen using Microsoft PowerPoint. The participants were instructed to familiarise themselves with each item before reading it out loud, and to produce each sentence as naturally as possible at a normal speech rate. Each item occurred only once in the list. The list of target items was preceded by three practice items (one simple sentence containing one-word subject, verb and object; one isolated noun; one question-answer pair) which were different from the experimental target and filler items. All utterances were recorded onto a Samsung laptop computer using an AKG C444 headset microphone with AKG B29L battery power supply and Audacity 1.1.3 software. They were later digitised into individual sound files using Cool Edit ${ }^{\mathrm{TM}} 96$. The individual sound files were analysed in PRAAT (Boersma, 2001).

\subsubsection{Data treatment}

The 12 speakers produced 46 target sentences with 47 target vowels each, adding up to 552 sentences containing 564 target vowels overall. The decision whether FVD had applied was made for all target items by listening and by looking at the spectrograms. To account for a possible degree in deletion, a distinction was initially made between 'vowel fully deleted', 'vowel very weak', 'vowel weak', and 'vowel fully retained'. All target vowels initially categorised in one of the intermediate classes ('very weak' and 'weak') underwent a careful second analysis after which only nine target vowels $(1.6 \%)$ remained in these two groups, five of which $(<1 \%)$ were 'very weak', four of which $(<1 \%)$ were 'weak'. For the purpose of the analysis reported on below, an intermediate definition of deletion was chosen such that the categories 'very weak' and 'fully deleted' were counted as 'deleted' and coded ' 1 ', whereas the categories 'weak' and 'fully pronounced' were analysed as 'retained' and coded ' 2 '. If a decision could not be made the item was categorised as 'unclear' and treated as an error in the analysis. Sentences with obvious speech errors and hesitations were also treated as erroneous. Overall, 30 tokens (5.4\% of all produced sentences) were erroneous. ${ }^{6}$

\subsection{The children's story Siggi og Stína}

The second data source was a recording of the well known children's story Siggi og Stina. The version used here was originally tape-recorded for use as a comprehension exercise in language teaching. It was read and recorded by a trained female speaker in a colloquial way. At the time of the recording, the speaker did not know that it would be used for any other purpose than her intended one. The recording was digitised into individual sound files for the purpose of the present study. From Chapters 1, 2 and 4 of the story (overall 118 sentences), all sentences containing relevant sequences of immediately adjacent words where w1 ended in an unstressed vowel followed by an initial vowel on w2 were extracted. 50 target vowel sequences entered the analysis. The materials were divided up according to the same criteria as used in the experimental

\footnotetext{
${ }^{6}$ In addition to the statistical analysis based on the intermediate definition of deletion, an analyses were run (i) based on a more conservative definition of deletion, where only 'fully deleted' vowels were treated as deleted, while 'very weak' vowels joined the 'retained' group, and (ii) on a more generous definition of deletion, where both 'very weak' and 'weak' vowels were counted as deleted along with the clearly deleted vowels. The results of both these analyses were essentially the same as for the intermediate definition.
} 
study, i.e., according to the strength of the syntactic boundary separating the two vowels in a sequence. Of the 50 items, 2 belonged to Group 1 (target vowels separated by a clause boundary), 20 to Group 2 (target vowels separated by an XP-boundary), and 28 to Group 3 (target vowels within the same XP). Examples are given in (11) through to (13).

(11) Group 1: Target vowels separated by a clause boundary (FVD predicted to be blocked)

a. $\quad$ Nú er kominn matartími, og Kalli á að vera kominn in.

Now is come dinner.time and Kalli has to be come in

'Now dinner time has come and Kalli should have come in.'

b. Hvaða fuglá pessa unga og hvernig hefur hann komizt inn?

Which bird has these young.ones and how has he come in

'To which bird do these chicks belong and how did it get in?'

(12) Group 2: Target vowels separated by an XP-boundary (here: subject-NP; FVD predicted to be blocked)

a. Mamma er búin að kalla á Kalla.

Mum is finished to call for Kalli

'Mum has called Kalli'

b. Jón og Gunna eiga heima á fjórðu hæð.

Jón and Gunna have home on fourth floor

'Jón and Gunna live on the fourth floor.'

(13) Group 3: Target vowels within one XP (FVD predicted to apply)
a. Drengirnir skoðuð $\underline{u}$ ungana góða stund.
the.boys looked.at the.young.ones good while
'The boys looked at the chicks for a while.'
b. Hún fór að leita að Kalla.
She went to search for Kalli
c. En preytandi er að ganga upp alla stigana.
But tiring is to walk up all the.stairs
'And it is tiring to walk up all the stairs.'
d. Heðan sjáum viðvel yfir borgina okkar.
(within VP)

From.here see we well over town-ACC.Sg.def our

'From here we have a good view over our town.'

The decision whether FVD had applied was made in the same way as described above. All target vowels were either clearly deleted or clearly retained. The data in Groups 2 and 3 were coded with respect to their syntactic structure and rhythmical patterns. ${ }^{7}$

\footnotetext{
${ }^{7}$ Note at this point in the discussion that experimental data Group 3 (vowel sequence within XP) only contains withinVP sequences, but not, for instance, within NP-sequences. In the story data, vowel sequences were found within VP (e.g., (13)(a)-(c)) and NP (e.g., (13)(d)), with the majority occurring within VP. A reviewer notes that for other languages, it has been shown that the two categories, VP and NP, may differ in relevant phrasing aspects (e.g., Nespor and Vogel, 1986; Ghini, 1993 for Italian; Frota, 2000 for Portuguese), and that in Icelandic, possible differences in phrasing might affect FVD application, such that it occurs more often in one phrasal category than in the other. For Icelandic, these differences between VP and NP will have to await careful experimental testing. Since the story data have naturally not been manipulated for any factor, safe conclusions as to the differences between FVD application in VP and NP are not possible based on the story data alone.
} 


\subsection{Additional materials}

After completion of both the experiment and the analysis of the story, one pair of sentences and one set of four sentences were specifically designed to further test the impact of eurhythmy on FVD application. These items are given in (14) and (15) below. (14) is based on an item from Siggi og Stína, while (15) is based on experimental material. In a pseudo-randomised order and along with a number of filler items, the six sentences were presented to the same speaker who also read Siggi og Stína. The speaker read all sentences three times, yielding a total number of 18 target tokens.

a. Trochee interrupted by sww sequence on tók nú upp
$\begin{array}{lllll}x & x & x & x\end{array}$
$\begin{array}{lllllllll}\mathrm{x} & \mathrm{x} & \mathrm{x} & \underline{\mathrm{x}} & \mathrm{X} & \mathrm{X} & \mathrm{x} & \mathrm{x} & \mathrm{x}\end{array}$

Helgi tók nú upp marga lykla.

Helgi took now up many keys

b. Regular dactyl

$\begin{array}{llll}x & x & x & x\end{array}$

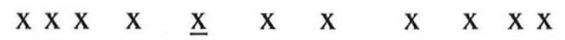

Jónina tók nú upp mjög marga lykla.

Jónina took now up very many keys

(15) a. Regular trochee

$\begin{array}{llll}x & x & x & x\end{array}$

$\begin{array}{llllllllll}\mathrm{x} & \mathrm{x} & \mathrm{x} & \mathrm{x} & \mathrm{x} & \underline{\mathrm{x}} & \mathrm{x} & \mathrm{x}\end{array}$

Auður gefur Önnu epli.

Auður gives Anna an.apple

b. Trochee interrupted by lapse on Maríu

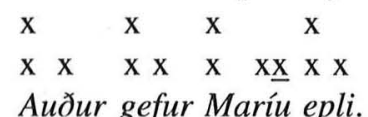

Auður gives Mary an.appl

c. Regular dactyl
$\begin{array}{llll}x & x & x & x\end{array}$
$\mathrm{x} \times \mathrm{x} \quad \mathrm{x} \times \mathrm{x} \quad \mathrm{x} \times \underline{\mathrm{x}} \times \mathrm{x} \times$
Jónína lofaði Maríu eplinu.

Jónína promised Mary the.apple

d. Dactyl interrupted by lapse on Sigurveigu
$\mathrm{x} \quad \mathrm{x}$

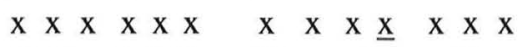
Jónína lofaði Sigurveigu eplinu.
Jónína promised Sigurveig the.apple

The items are designed such that the syntactic structure remains the same within the two sets, while the rhythmical pattern changes. In (14)(a), taken from Siggi og Stina, we have a regular trochaic pattern except for the sequence tók nú upp, which is dactylic, while in (14)(b), we have a regular dactyl. In syntax, both target vowels are in the same VP with their adjacent vowels and deletion is thus predicted to apply. The target vowels in (15) are separated by the phrasal 
boundary between the two nominal objects, suggesting blocking of FVD. The rhythmical pattern is varied such that the regular trochee in (15)(a) is interrupted in target position in (15)(b), while the regular dactyl in (15)(c) is interrupted in target position in (15)(d). Based on the rhythmical pattern, FVD application is thus predicted to be blocked in (15)(a) and (15)(c), but predicted to apply in (15)(b) and (15)(d).

\section{Results}

\subsection{Results of the experimental study}

All final vowels were retained on the words presented in isolation. In the experimental items, no speaker retained or deleted all target vowels.

Group 1 was designed to test FVD application at a syntactic clause boundary. Due to the strength of this boundary, FVD was predicted to be blocked. Overall, the 12 speakers produced 36 target sequences. None of the target vowels were dropped across all speakers. The prediction was thus borne out, suggesting that FVD does not apply across clause boundaries in syntax.

Group 2 was designed to test FVD application at a syntactic XP boundary. The prediction was that the target vowels should fail to undergo deletion if bound by the XP. Deletion was supposed to be less likely than within XP. Overall, the 12 speakers produced 456 target sequences (192 at the boundary of type Subj-NP][VP, 120 between the two objects of a double object construction, 72 between the second of two objects and a phrasal adjunct, and 72 between a nominal object and a verbal particle). $99(22 \%)$ of the target vowels were deleted against the predictions based on syntactic structure. The results by positions are as follows. Of the 192 target vowels produced at the end of a subject, 47 (24\%) were deleted. $26(22 \%)$ of 120 vowels were deleted between two objects, $9(13 \%)$ of 72 vowels were deleted at the end of an object preceding a phrasal adjunct, and $17(24 \%)$ of 72 vowels were deleted between object and verbal particle. Within the subgroup 'SubjectNP][VP' (cf. (9)(a)), both the syntactic length/complexity of the subject and focus affected the application of FVD such that FVD was more frequent with simple subjects as opposed to complex subjects, and under narrow subject focus as compared to wide focus (cf. Fig. 1). Accordingly, the rate of FVD application was highest on a simple subject under narrow focus (cf. column 3 in Fig. 1), and lowest on a complex subject under wide focus (cf. column 2 in Fig. 1).

Group 3 was designed to test FVD application within an XP, here on the verb followed by a nominal complement. According to predictions, FVD was most likely to occur in this group due to the lack of a phrasal boundary. Two focus conditions were tested: broad focus and narrow verb focus. Overall, 72 items were produced by the 12 speakers, 36 in each focus condition. No items were erroneous. For each target vowel, there was at least one speaker who deleted it. Four

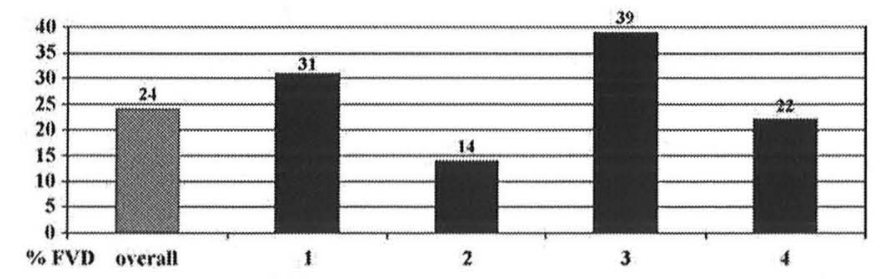

Fig. 1. Group 2, subgroup Subj-NP][VP, results overall and by focus and subject type, in \% FVD application. (1) Simple Subj, wide focus: Jónína eldar ekki fisk. (2) Complex Subj, wide focus: Birna og Jónína elda ekki fisk. (3) Simple Subj, Subj focus: [Jónina $]_{\mathrm{Foc}}$ eldar ekki fisk. (4) Complex Subj, Subj focus: [Birna og Jónína $]_{\mathrm{Foc}}$ elda ekki fisk. 
speakers deleted all target vowels. Overall, $58 \%$ of all target vowels were deleted. The results were completely identical in both focus conditions, which means that in this data set at least, focus did not affect FVD application in any way. $42 \%$ of the target vowels were retained contrary to the predictions based on syntactic information.

In order to further test hypothesis (i) (the stronger the syntactic boundary, the less likely FVD is to apply), the response values for the three groups were submitted to an analysis of variance with the factor Boundary Strength (three levels: Groups 1, 2 and 3; cf. (8) through to (10) above). With regard to the application of FVD, a main effect was obtained $(F[2,11]=13.842$, $p<0.001)$. All individual comparisons between the groups revealed significant differences, confirming the differences between the groups and the role of the strength of the boundary. Deletion in Group 2 (XP-boundary) was significantly more frequent than deletion in Group 1 (clause boundary) $(t(11)=-3.361, p<0.01)$; deletion in Group 3 (no syntactic boundary) was significantly more frequent than deletion in Group 1 (clause boundary) $(t(1)=-4.836$, $p=0.001$ ); and finally, deletion in Group 3 (no syntactic boundary) was significantly more frequent than deletion in Group 2 (XP-boundary) $(t(11)=-4.240, p=0.001)$. An analysis was also done within Group 2 (XP-boundary) comparing the four different XP boundary positions. No significant results were obtained suggesting that FVD application is equally likely at the end of XPs of different syntactic functions and in different syntactic environments.

Within the subgroup 'Subject-NP][VP' of Group 2 (cf. (9)(a)), the effect of both focus and complexity was confirmed by an analysis of variance to which the response values were submitted. With regard to FVD application, main effects were found for both the factor Focus $(F[1,11]=8.80, \operatorname{MSE}<1, p<0.02)$ and the factor LeNGTH $(F[1,11]=6.60, \quad M S E<1$, $p<0.03)$. No interaction was found between the two factors.

These results suggest that FVD application is sensitive to and clearly reflects the strength of syntactic boundaries in line with hypothesis (i): it is most frequent at a clause boundary and least frequent within an XP. However, FVD application is not predictable on the basis of syntactic structure alone. It fails to be obligatory where it is predicted, i.e., within an XP, and it often applies where it is predicted to be blocked, e.g., at the right edge of an XP. Focus may (cf. Group 2, Subgroup 'Subject][VP') but does not have to (cf. Group 3) affect FVD application. If it does have an effect, it enhances FVD application rather than inhibiting it. Another factor which may affect FVD application is the length of a constituent such that the longer it is, the less likely FVD application. In section 4 below, the results will be interpreted in prosodic rather than syntactic terms.

\subsection{Results from the children's story Siggi og Stína}

For the target items taken from Siggi og Stina, the picture is similar to the experimental results. Overall, deletion becomes less likely, the stronger the syntactic boundary. Of the two target vowels separated from the following one by a clausal boundary, one was retained (cf. section 4.1 below for interpretation). In the XP boundary group, $6(30 \%)$ of the 20 target vowels were deleted, while 14 (70\%) were retained. And finally, FVD applied to 25 (89\%) of the 28 target vowels followed by an initial vowel within the same XP, while deletion of 3 vowels $(11 \%)$ was blocked.

Regarding hypothesis (i) (syntax), these results are consistent with the experimental findings reported in the previous section: application of FVD is most frequent within syntactic phrases. However, deletion is not obligatory within syntactic phrases, and it is possible across syntactic boundaries.

A closer look at the items which allowed FVD application reveals the impact of eurhythmy. In Group 2 (XP-boundary), the deletion of all 6 target vowels for which FVD was observed 
contributed to a more regular rhythmic pattern. In Group 3 (vowel sequence within XP), blocking of FVD deletion can be accounted for along the lines of eurhythmy in all three cases. Examples are given in (16). (16)(a) is an example of deletion across an XP-boundary. FVD application on Stín $u$ was predicted to be blocked due to its position at the end of the subject and the XP-boundary accordingly separating the two vowels in the sequence. However, the underlined target vowel was deleted in the interest of lapse resolution. (Note that the final vowel on Sigga was also deleted for the same reason.) In (16)(b), the two vowels in the target sequence are within one XP, thus FVD was predicted to apply on the basis of syntactic information. However, the vowel was retained by the speaker, maintaining the regular dactylic pattern.

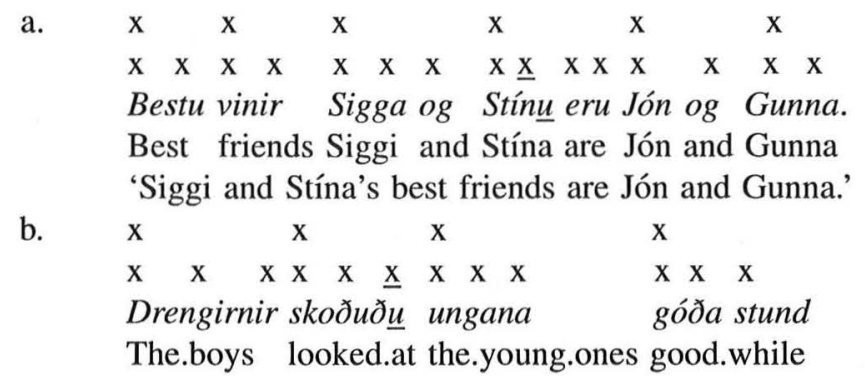

\subsection{Results from the additional materials}

The two data sets behaved according to the predictions made on the basis of the rhythmical pattern. In (14)(a), the speaker deleted the final vowel on nú in all three repetitions, resulting in a regular trochaic pattern. This is also in line with the syntactic structure. Note that here, unlike all other cases, the nucleus of a monosyllabic word (adverb) is deleted. It seems that the adverb may get destressed here, so that the then unstressed vowel may be deleted. In (14)(b), deletion of the final vowel on nú is blocked in all three repetitions, despite the fact that the syntactic structure remains unchanged, and also against the corresponding syntax-based predictions. The regular dactylic pattern is thus retained, suggesting that rhythmic constraints overrule syntactic information in this example.

The items in (15) are identical in syntactic structure. FVD was predicted to be blocked on the basis of syntactic information due to the position of all target vowels at an XP-boundary. However, the items vary in rhythmical structure. As predicted on the basis of rhythmical information, the speaker deleted the target vowels in (15)(d) in all three repetitions, and the target vowel in (15)(b) in two of the three repetitions. In both examples, FVD application serves to resolve lapses. In (15)(b), it results in a regular trochaic pattern, while in (15)(d), it results in a regular dactylus. Unlike the desired consequences of FVD in (15)(b) and (d), deletion of the final vowel on Öпnи in (15)(a) would have resulted in an irregular pattern and yielded a stress clash. Similarly, in $(15)(\mathrm{c})$, the regular dactylic pattern is saved by the speaker by vowel retention.

\section{Discussion}

\subsection{Discussion of the results in Group 1: Target vowels separated by a clause boundary}

Due to the strong syntactic boundary, deletion of a word-final target vowel separated from an adjacent word-initial vowel by a clause boundary was predicted to be blocked. Also, according to 
previous research on intonational phrasing, a clause boundary in syntactic structure typically coincides with an Intonational Phrase (IP) boundary in prosodic structure (cf. Gussenhoven, 2004:287 and references given there). Árnason (1998:58) shows for Icelandic that parts of a listing each form their own IP and he also indicates that the same holds for coordinated clauses. ${ }^{8}$

Both items in experimental Group 1 are listings of clauses. Under the assumptions that FVD is blocked across syntactic clause boundaries and that it does not apply across Intonational Phrase boundaries, it should thus be blocked in the data in Group 1. This prediction is borne out in the experimental data, where all target vowels in the relevant positions are retained across all speakers and items. (Note that due to the nature of the materials vowel deletion would not have resulted in a stress clash.) These results suggest that FVD is indeed bound by the clause in syntax, and the results are also compatible with the assumption that FVD is blocked across Intonational Phrase boundaries.

However, in the data drawn from Siggi og Stína, one out of two vowels was deleted at a clause boundary. The relevant item is repeated in (17).

$$
\begin{aligned}
& \text { Hvaða fugl á pessa unga og hvernig hefur hann komizt inn? } \\
& \text { Which bird has these young.ones and how has he come in } \\
& \text { 'To which bird do these chicks belong and how did it get in?' }
\end{aligned}
$$

The deletion of the vowel in this position can best be explained under the assumption that it is the Intonational Phrase boundary rather then the syntactic clause boundary which is relevant to FVD application. Under the assumption that the clause boundary is mapped onto an IP boundary, we expect the presence of an IP boundary between the two conjuncts, i.e., separating unga and the coordinating conjunction og. However, it has been shown in recent research on intonation in discourse that coordinators such as and and but may phrase with the preceding rather than the following material (e.g., Barth-Weingarten, in press). This is exactly what happens in this example. In all other items involving clause boundaries we observe 'comma intonation' in the relevant position, i.e., a continuation rise followed by a pause (cf. Árnason, 1998; Dehé, 2007 for utteranceinternal $\mathrm{H} \%$ indicating continuation in Icelandic). In the unga example in (17), the pitch fall starting on the first (nuclear) syllable of unga is continued on $o g$ before an audible break and a step-up in pitch on hvernig. It follows from this that there is no Intonational Phrase boundary between unga and $o g$, allowing for FVD to apply. Under the assumption that it is the syntactic clause boundary that blocks FVD application, deletion in this particular example cannot be accounted for.

In short, while FVD is not obligatorily blocked by a clause boundary in syntactic structure (the strongest syntactic boundary tested here), all results can be accounted for under the assumption that FVD is bound by the IP in prosody.

\subsection{Discussion of the results in Group 2: Target vowels separated by an XP-boundary}

To a significant degree, deletion at a syntactic XP-boundary is more frequent than at a clause boundary, and less frequent than within an XP, reflecting the respective hierarchy. Syntax,

\footnotetext{
${ }^{8}$ As above (cf. fn.3), I follow the prosodic hierarchy as widely agreed on in the literature. In this work, the Intonational Phrase (IP) has been defined as the domain of a complete intonational contour. Its edge is aligned with a boundary tone and may coincide with a pause. As has been shown by Árnason (1998) and Dehé (2007), Icelandic has (at least) two boundary tones: a high one $(\mathrm{H} \%)$ and a low one ( $\mathrm{L} \%)$. The IP is made up of one or more prosodic constituents one level down in the hierarchy (i.e., the Phonological Phrase).
} 
however, fails to account for the fact that FVD applies to a considerable percentage of target vowels in this group, indicating that other factors may override syntax. One such factor is focus: FVD applies across an XP boundary more frequently if the relevant constituent is narrowly focused than in an all new context. I believe that these results, too, can best be accounted for under the assumption that it is prosodic constituency rather than syntactic constituency that has an effect on FVD application. Assume that a syntactic XP-boundary right-aligns with a Phonological Phrase boundary (Align-R, XP; cf. Selkirk, 1986, 2000 and much related work), that the domain for FVD application is the Phonological Phrase, and that focus may soften the strength of a prosodic boundary. This last point is reminiscent of Korean where focus may erase a phrasal prosodic boundary (cf. Cho, 1990), but unlike languages where focus may further a prosodic boundary, such as for instance Bengali (Hayes and Lahiri, 1991), Chicheŵ (Kanerva, 1990), and Shanghai Chinese (Selkirk and Shen, 1990), and also unlike European Portuguese, where focus does not seem to affect prosodic phrasing at all (Frota, 2002). In the present data, the two vowels in a target sequence are separated by a Phonological Phrase boundary under broad focus, which helps to block FVD application. Under narrow subject focus, the Phonological Phrase boundary may be erased placing the subject and adjoining verb (i.e., both vowels in a target sequence) in one Phonological Phrase, thus allowing for FVD to apply.

It also follows from the results in this group that the overall rhythmic pattern may lead to deletion across XP boundaries. The examples given in (18) through to (22) represent the items and target vowels from Siggi og Stina in this data group, for which FVD application was observed.

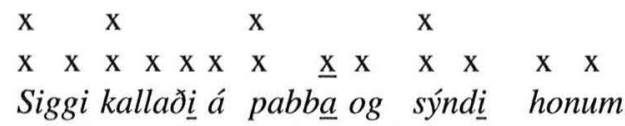

Siggi called to dad and showed him

\begin{tabular}{|c|c|c|}
\hline \multirow[t]{2}{*}{$\mathrm{x}$} & $\mathrm{X}$ & $\mathrm{x}$ \\
\hline & $\mathrm{X} \quad \underline{\mathrm{x}} \mathrm{X}$ & $\mathrm{x} \quad \mathrm{X} \quad \mathrm{x}$ \\
\hline
\end{tabular}

Allir komú og horfoú á Kalla.

Everybody came and looked at Kalli.

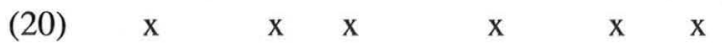

$\begin{array}{llllllllllllllllll}\mathrm{x} & \underline{\mathrm{x}} & \mathrm{x} & \mathrm{x} & \mathrm{x} & \mathrm{x} & \mathrm{x} & \mathrm{x} & \mathrm{x} & \underline{\mathrm{x}} & \mathrm{x} & \mathrm{x} & \mathrm{x} & \mathrm{x} & \mathrm{x}\end{array}$

Siggị er níu ára, en Stína er átta ára.

Siggi is nine years and Stína is eight years

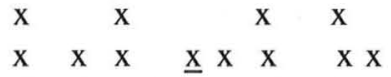

Húsið peirra er fimm haððir.

House their is five levels

'Their house has five floors.'

\begin{tabular}{|c|c|c|c|c|c|c|}
\hline $\mathrm{x}$ & $\mathrm{X}$ & $x$ & & $x$ & $\mathrm{x}$ & $\mathrm{x}$ \\
\hline$x \quad x$ & $\mathrm{x} \quad \mathrm{x}$ & $\mathrm{x}$ & $x$ & $\mathrm{x} \quad \underline{\mathrm{x}}$ & $\mathrm{x} \times \mathrm{x}$ & $x \quad x$ \\
\hline Bestu & vinir & Sigg $\bar{a}$ & $o g$ & Stín $\underline{\bar{u}}$ & eru Jón o & Gunna. \\
\hline
\end{tabular}


Both (18) and (19) are cases of VP coordination. The target vowel is positioned at the right edge of the first VP. In (18), the final vowel on pabba was deleted despite its position at a VP-boundary. Note that in this example, the final vowels on kallaði and sýndi, both within maximal projections, were deleted, too, such that FVD applied three times to resolve lapses. Similarly, in (19), deletion applied to both the final vowel on komu and the (VP-internal) vowel on horf $\partial$, resulting in a regular trochee. Example (20) contains two vowels in target positions. The final vowels on both Siggi and Stína were deleted in the interest of lapse resolution. In (21), deletion of the final vowel on peirra, i.e., at the right edge of the subject-NP, resulted in a more regular stress pattern. And finally, deletion of the final vowel on Stínu in (22) also applied as a means to remedy a stress lapse. The final vowel on Sigga in this example was also deleted resulting in an almost regular trochaic pattern. Since the final vowel on eru is not followed by an initial vowel on the next word, a completely regular trochee cannot be formed by FVD application, but other means to remedy lapses, such as speeding up, might apply (cf. e.g., Nespor and Vogel, 1989 who suggest speeding up as a means to remedy lapses between two strong syllables in stress-timed languages). The strategies Icelandic employs to remedy lapses (and clashes), other than the application or blocking of FVD, remains to be explored in future research. Note, however, that the availability of other means to deal with lapses (such as possibly speeding up) may also explain why in examples such as (23), taken from the experimental data set, the target vowel was deleted by some but not all participants. Deletion of the target vowel on töskuna resolved the lapse of three weak syllables in a row in an otherwise dactylic pattern.

$$
\begin{aligned}
& \begin{array}{llllllllll}
\mathrm{x} & \mathrm{x} & \mathrm{x} & \mathrm{x} & \mathrm{x} & & \mathrm{x}
\end{array}
\end{aligned}
$$

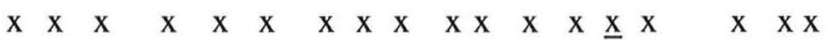

$$
\begin{aligned}
& \text { Maðurinn aetlar að gefa barninu töskuña um helgina. }
\end{aligned}
$$

\subsection{Discussion of the results in Group 3: Target vowels within one XP}

According to the initial hypotheses, deletion was most likely to occur within a syntactic XP, and deletion is in fact most frequent if the target vowel sequence is located within the same XP. However, it follows from both the experimental results and the data drawn from Siggi og Stina that deletion within XP is not obligatory. Of all target vowels in this category, $42 \%$ in the experimental data and $11 \%$ in the Siggi og Stína data were retained. Phrasing can thus account for the majority, but not all of the data. Of the other factors potentially affecting FVD application, focus has been shown to be without effect in this data set. One factor that is clearly at work in this group, too, is eurhythmy. For illustration, I will take a closer look at the three items from Siggi og Stína which did not behave according to the predictions based on phrasing. They are given in (24) through to (26).

$$
\begin{aligned}
& \begin{array}{llllll}
X & x & x & X
\end{array}
\end{aligned}
$$

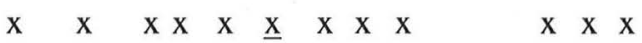

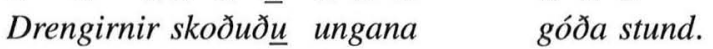

The.boys looked.at the.young.ones good.while

$$
\begin{aligned}
& \begin{array}{llllllll}
x & & x & x & & x & x
\end{array} \\
& \begin{array}{llllllllll}
\mathrm{x} & \mathrm{X} & \mathrm{X} & \mathrm{X} & \mathrm{X} & \mathrm{x} & \mathrm{X} & \mathrm{x} & \underline{\mathrm{x}} & \mathrm{x}
\end{array} \\
& \text { Fuglinn porir ekki að koma inn. }
\end{aligned}
$$

The.bird dared not to come in 


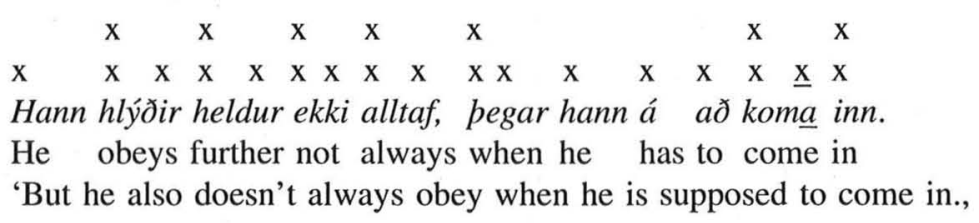

In (24), which was also discussed in section 3.2 above, the target verb skoðuðu is in the same phrase with its complement ungana. The speaker retained the final vowel on skoðuðu. Vowel deletion would have resulted in a departure from the regular dactyl. The items in (25) and (26) involve the verb koma plus directional particle inn. Deletion of the final vowel on koma was blocked because it would have resulted in a stress clash. This is because inn, being a verbal particle, is stressed while the first syllable of koma is also strong. (Note that at a phrasal level, the particle inn is most prominent due to its sentence-final position.) In (25), the final vowel on $e k k i$ was also deleted in the interest of a regular trochee.

\subsection{General discussion}

In this section, the four hypotheses formulated in section 1 above and repeated directly below will be addressed in turn.

(i) The stronger the syntactic boundary, the less likely FVD is to apply.

(ii) The stronger the prosodic boundary, the less likely FVD is to apply.

(iii) Eurhythmy may affect the application of FVD.

(iv) Focus may affect the application of FVD.

Firstly, supporting evidence has been found for hypothesis (i). FVD is indeed less likely to apply, the stronger the syntactic boundary. It is most likely to apply within a syntactic XP, and least likely across a clause boundary. These results have been confirmed statistically based on the experimental data. However, syntax alone cannot account for the results. We find cases of vowel retention where FVD is predicted to apply (i.e., within XPs) and of vowel deletion where it is predicted to be blocked (i.e., at an XP or clause boundary). It follows from the results, for instance, that blocking of FVD at a clause boundary fails to be obligatory, depending on the prosodic structure of the utterance. If the clause boundary does not coincide with a phrasal prosodic boundary, FVD may apply (cf. section 4.1, above). This suggests a certain relevance of prosodic phrasing to FVD application. Moreover, XP-edges also fail to fully predict FVD application. Syntactic constraints on FVD application interact with and may be overridden by eurhythmy, constituent size, and focus. Focus and eurhythmy will be addressed separately immediately. Constituent size affected FVD application in subset 'Subject-NP][VP' of experimental data Group 2 (reported in section 3.1). Essentially, the data include subjects consisting of one $\mathrm{N}$ on the one hand, and coordinated subjects of the form ' $\mathrm{N}$ and $\mathrm{N}$ ' and pre-modified Ns on the other hand. None of the complex subjects contains more than two prosodic words, and FVD is more frequent with less complex subjects. Although constituent size was not systematically controlled for, these preliminary results suggest that this factor plays a role and this finding can best be explained under the assumption that it is prosodic phrasing rather than syntactic phrasing that is dominant in FVD application. Under Align-XP, the edge of the subject is predicted to coincide with a phrasal prosodic boundary. On the other hand, it has been shown in much previous research and for many languages that both syntactic and prosodic 
complexity may affect prosodic phrasing (e.g., D'Imperio et al., 2005; Elordieta et al., 2005; Ghini, 1993; Meinschaefer, in press; Nespor and Vogel, 1986; Sandalo and Truckenbrodt, 2002; Prieto, 2005; Selkirk, 2000). It is thus not unlikely that in the cases of the shorter, less complex subject-NPs, the Phonological Phrase boundary following the subject is shifted to the right, thus placing the target vowel sequence in one such domain and allowing for FVD to apply.

Secondly, the relevance of phonological phrasing (cf. hypothesis (ii)) is evident in particular from the results regarding the impact of syntactic structure and focus. It is a fact that syntax cannot fully define the contexts of FVD application. Rather, in the analysis above, eurhythmy, focus and constituent size have been shown to also play a role. These results can best be explained under the assumption that it is prosodic rather than syntactic structure which governs FVD application. Much previous work in prosodic phonology has shown that prosodic phrasing can be derived from syntactic structure (e.g., Nespor and Vogel, 1986; Selkirk, 1986, 1995 and related work; Truckenbrodt, 1995, 1999), but that a number of other factors have to be taken into account, too, among them focus (e.g., Cho, 1990; Frota, 2002; Hayes and Lahiri, 1991; Kanerva, 1990; Selkirk, 2000; Selkirk and Shen, 1990), and syntactic and prosodic constituent size (cf. above for references), i.e., exactly the same factors that also have an impact in the present study. In other words, the frequency of FVD application decreases with an increasing strength of syntactic boundaries not because of their syntactic nature, but because stronger syntactic boundaries are mapped onto stronger prosodic boundaries. The results regarding the hierarchy of syntactic phrase edges thus reflect the relation between syntactic and prosodic structure and the prosodic hierarchy. For instance, it follows from the discussion in section 4.1 above that FVD is obligatorily blocked at the right edge of an Intonational Phrase rather than at the right edge of a syntactic clause. Moreover, the fact that constituent size and focus play a role in FVD application to vowels terminating a subject-NP suggests that it is the Phonological Phrase boundary rather than the XP boundary that is involved. Since there is no detailed study of Icelandic prosodic phrasing to date, the exact nature of the relation between syntactic and prosodic constituency and the impact of the other factors has to await future research, but the present findings support the assumption that in Icelandic, just like other languages, prosodic phrasing (along with the factors by which it is governed) plays a role in phonological rule application.

Thirdly, it follows from the results drawn from all three data sources that eurhythmy may indeed affect the application of FVD (cf. hypothesis (iii)). The rhythmical pattern may force both retention of a vowel that is otherwise predicted to be deleted, and deletion of a vowel that is otherwise predicted to be retained. While some instances of vowel retention simply function to avoid a stress clash (cf. for instance, the discussion of examples (15) (a), (25) and (26)), other instances of retention/deletion can best be explained by looking at the larger rhythmical structure. Specifically, FVD may apply within and across phrases in order to arrive at a constant pattern such as a trochee or dactyl, i.e., it applies to remedy stress lapses. By the same token, its application may be blocked within and across phrases if deletion will result in the departure from an already regular rhythmic pattern (e.g., a regular dactyl). In other words, information about syntactic phrase edges and also Phonological Phrase edges may be overridden by rhythmical constraints. Examples of this have been discussed in sections 4.2 and 4.3 above. These results, specifically the fact that vowel deletion may occur across phrase edges in the interest of lapse resolution, are compatible with previous research using data from other languages according to which it is the Intonational Phrase that is the domain for rhythmic adjustments and other rhythmic processes (e.g., Frota, 2000 for European Portuguese). While it seems that the relevant boundary for FVD application is that of the Phonological Phrase, the domain for rhythmic adjustments is 
the Intonational Phrase, allowing for vowel deletion across Phonological Phrase boundaries, and for vowel retention within boundaries.

And fourthly, focus may indeed affect the application of FVD (cf. hypothesis (iv)), but only if the target vowel sequence is located across a syntactic XP boundary. It follows from this that focus may not affect FVD application directly. Rather, it interacts with prosodic constituent structure. I have argued above that the results can best be accounted for under the assumption that the domain for FVD application is the Phonological Phrase, and that focus may soften the strength of a prosodic boundary. Under broad focus, the two vowels in a target sequence in Group 2 are separated by a Phonological Phrase boundary, which helps to block FVD application. Under narrow subject focus, the Phonological Phrase boundary may be erased placing the subject and adjoining verb (i.e., both vowels in a target sequence) in one Phonological Phrase, and allowing for FVD to apply. In Group 3, on the other hand, the target vowel sequence is within the same XP, thus within the same Phonological Phrase. In this case, narrow verb focus does not affect FVD application because both in the broad focus condition and in the narrow verb focus condition, the verb ending in the target vowel is in the same Phonological Phrase with its adjacent vowel. The fact that the results for broad focus items and narrow focus items are completely identical thus follows straightforwardly. Note also that the effects of the factors focus and constituent size go in the same direction, accounting for the results in the relevant subset of experimental data Group 2, illustrated in Fig. 1.

Overall, evidence has been found in support of all four hypotheses, yet the interpretation of the results is more subtle than the hypotheses suggest. I have argued, for example, that focus affects FVD application (hypothesis (iv)), but that it does not do so directly, but via its impact on prosodic phrasing. Also, the syntactic hierarchy is reflected in the results, but this is because of the relation between syntactic and prosodic structure rather than syntax alone. Taking everything into account, it seems fair to conclude that it is prosodic rather than syntactic constituency that governs FVD application, along with eurhythmy whose domain seems to be the Intonational Phrase.

\section{Conclusion}

In light of the results reported above, the following conclusions can be drawn. Syntactic information is insufficient to fully account for the contexts of the application of Icelandic FVD. Prosodic constituency plays a crucial role but fails to explain the full pattern. This is mainly because of the effect of eurhythmy on phonological rule application. Moreover, focus affects FVD application indirectly via its impact on prosodic phrasing.

Icelandic FVD is thus not an optional phonological rule, but its application can be accounted for along the lines of well-understood prosodic principles. Its application is governed by prosodic boundaries. Like in other languages, prosodic constituency seems to be determined by at least the factors syntactic structure, focus structure and constituent size. The domain of rhythmic adjustments is the Intonational Phrase, which explains the impact of eurhythmy within and across Phonological Phrase boundaries.

\section{Acknowledgements}

An early version of this paper was presented at the Tone and Intonation [ \pm Europe] Workshop in Konstanz (Schloss Freudental) in March 2005. I would like to thank the audience there for the lively and fruitful discussion. I would also like to thank the participants of the 19th Annual Rask 
Conference held at the University of Iceland in January 2005 for their comments. I am indebted to the following people who have contributed in various ways and at various stages to the work presented here: Kristján Árnason, Laura Downing, Thorhallur Eythorsson, Ragnheiður Guðmundsdottir, Carlos Gussenhoven, Gunnar Hrafn Hrafnbjargarson, Jill House, Jóhannes G. Jónsson, Bob Ladd, Aditi Lahiri, Judith Meinschaefer, Ad Neeleman, Vieri Samek-Lodovici and Moira Yip. Thanks are furthermore due to the anonymous reviewers, who gave me a hard time but whose comments were very valuable indeed, and to the participants of the reading study. The work presented here was supported by DFG grant DE $876 / 1$ to the author.

\section{Appendix A. Experimental items}

All target vowels are underlined.

Group 1: Target vowels separated by a clause boundary (two items, three target vowels) e101 Auður hjálpaði barninu, Anna hjálpaði konunni, Elísabet hjálpaði lakninum. e102 Elísabet kenndi barninu, Niels kenndi konunni, Anna kenndi bóndanum.

Group 2: Target vowels separated by an XP-boundary (38 items, 38 target vowels)

(a) Subject-NP] [VP

\begin{tabular}{|c|c|}
\hline $\mathrm{e} 201$ & wide focus \\
\hline e201f & Subject focus \\
\hline $\mathrm{e} 202$ & wide focus \\
\hline e202f & Subject focus \\
\hline $\mathrm{e} 203$ & wide focus \\
\hline e203f & Subject focus \\
\hline e204 & wide focus \\
\hline e204f & Subject focus \\
\hline e205 & wide focus \\
\hline e205f & Subject focus \\
\hline $\mathrm{e} 206$ & wide focus \\
\hline e207 & wide focus \\
\hline e208 & wide focus \\
\hline e209 & wide focus \\
\hline e209f & Subject focus \\
\hline 210 & wide focus \\
\hline
\end{tabular}

(b) V Object-NP] [Object-NP

$$
\begin{aligned}
& \text { e211 } \\
& \text { e212 } \\
& \text { e213 } \\
& \text { e214 }
\end{aligned}
$$

Jónína atlar að baka köku.

(Hver atlar að baka köku?)

Jónína atlar að baka köku.

Gísli átti fimm braðður.

(Hver átti fimm braður?)

Gísli átti fimm braeður.

Birna og Jónína elda ekki fisk.

(Hver eldar ekki fisk?)

Birna og Jónína elda ekki fisk.

Systir mín Jónína aetlar að hjálpa Hildi.

(Hver atlar að hjálpa Hildi?)

Systir mín Jónína aetlar að hjálpa Hildi.

Guðni og Birna elda lambakjöt og kartöflur.

(Hver eldar lambakjöt og kartöflur?)

Guðni og Birna elda lambakjöt og kartöflur.

Anna atlar að lara íslensku.

Maggi og Bjarnị atluðu að baka köku í gar.

Anna og Jónína elda stundum svínakjöt og hrísgrjón.

Jónína eldar stundum fisk.

(Hver eldar stundum fisk?)

Jónína eldar stundum fisk.

Ragga og Guðni attla að ganga yfir Fimmvörðuháls.

Auður gaf barninu afmalisgjöf.

María gaf barninu epli.

Elisabet gaf barninu appelsínu.

Anna sýndi konunni armbandsúr. 
e215

e216

e217

e218

e219

e220

(c) Object-NP] [PP

e221

e222

e223

e224

e225

e226

Kennslukonan gaf barninu orðabók.

Elín gaf kennslukonunni afmaelisgjöf.

Gísli gaf konunni appelsínu.

Guðni gaf kennslukonunni orðabók.

Húseigandinn sýndi konunni íbúðina.

Kennarinn gaf barninu ípróttatöskuna.

Konan atlar að gefa barninu banana annað kvöld.

Húseigandinn oetlar að sýna konunni íbúdina um helgina.

Gísli atlar að sýna konunni kirkjuna annað kvöld.

Kennarinn gaf barninu ípróttatöskuna i kaffinu.

Elísabet atlar að sýna konunni kirkjuna í hádeginu.

Maðurinn atlar að gefa barninu töskuna um helgina.

(d) Object-NP] [verbal particle

$\begin{array}{ll}\text { e227 } & \text { V Obj1 Part Obj2 } \\ \text { e228 } & \text { V Obj1 Obj2 Part } \\ \text { e229 } & \text { V Obj1 Part Obj2 } \\ \text { e230 } & \text { V Obj1 Obj2 Part } \\ \text { e231 } & \text { V Obj1 Part Obj2 } \\ \text { e232 } & \text { V Obj1 Obj2 Part }\end{array}$

Gísli sendi konunni út peningana.

Gísli sendi konunni peningana út.

Anna gaf konunni upp símanúmerið.

Anna gaf ritaranum utanáskriftina upp.

Maðurinn sendi konunni út orðabókina.

Maðurinn sendi nemendunum orðabókina út.

Group 3: Target vowels within one XP (here: VP) (6 items, 6 target vowels)

e301 wide focus

Jón kastaði appelsínunni.

e301f $\quad V$ focus

(Hvað gerði Jón við appelsínuna?)

e302 wide focus

Jón kastað $\underline{i}$ appelsínunni.

María borðaði appelsínuna.

e302f V focus

(Hvað gerði María við appelsínuna?)

María borðaði appelsínuna.

e303 wide focus

Húseigandinn borðað $\underline{i}$ appelsínuna.

e303f V focus

(Hvað gerði húseigandinn við appelsínuna?)

Húseigandinn borðað $\underline{i}$ appelsínuna.

\section{References}

Abousalh, E.S. Ferreira, 1997. Resolução de choques de acento no português brasileiro: Unpublished Master Thesis. Universidade Estadual de Campinas (UNICAMP), Brazil.

Árnason, K., 1985. Icelandic word stress and metrical phonology. Studia Linguistica 39, 93-129.

Árnason, K., 1987. The stress of prefixes and suffixes in Icelandic. In: Gregersen, K., Basbøll, H. (Eds.), Nordic Prosody IV: Papers from a Symposium. Odense University Press, pp. 137-146.

Árnason, K., 1998. Toward an analysis of Icelandic intonation. In: Werner, S. (Ed.), Nordic Prosody. Proceedings of the VIIth Conference, Joensuu 1996. Peter Lang, Frankfurt a.M./Newyork, pp. 49-62.

Árnason, K., 2005. The standard languages and their systems in the 20th century I: Icelandic. In: Bandle, O., et al. (Eds.),

The Nordic Languages: An International Handbook of the History of the North Germanic Languages, vol. 2. Walter de Gruyter, Berlin/New York, pp. 1560-1573.

Barth-Weingarten, D. Prosody, Construction Grammar and language change. Anglistentag 2006, Halle, Proceedings.

Wissenschaftlicher Verlag, Trier, in press.

Boersma, P., 2001. Praat, a system for doing phonetics by computer. Glot International 5, 341-347.

Casali, R.F., 1997. Vowel elision in hiatus contexts: which vowel goes? Language 73, 493-533. 
Cho, Y.Y., 1990. Syntax and phrasing in Korean. In: Inkelas, S., Zec, D. (Eds.), The Phonology-Syntax Connection. The University of Chicago Press, Chicago, pp. 47-62.

Collins, C., Thráinsson, H., 1996. VP-internal structure and object shift in Icelandic. Linguistic Inquiry 27, $391-444$

Cooper, W.E., Paccia-Cooper, J., 1980. Syntax and Speech. Harvard University Press, Cambridge, MA.

Dehé, N., 2007. An Intonational Grammar for Icelandic. Ms., Freie Universität Berlin/Universität Konstanz.

D'Imperio, M., Elordieta, G., Frota, S., Prieto, P., Vigário, M., 2005. Intonational phrasing in romance: the role of syntactic and prosodic structure. In: Frota, S., Vigário, M., Freitas, M.J. (Eds.), Prosodies-With Special Reference to Iberian Languages. Mouton de Gruyter, Berlin/New York, pp. 59-97.

Einarsson, S., 1973. Icelandic: Grammar, Texts, Glossary, 2nd ed. The John Hopkins University Press, Baltimore.

Elordieta, G., Frota, S., Vigário, M., 2005. Subjects, objects and intonational phrasing in Spanish and Portuguese. Studia Linguistica 59, 110-143.

Frota, S., 2000. Prosody and Focus in European Portuguese: Phonological Phrasing and Intonation. Garland, New York.

Frota, S., 2002. The prosody of focus: a case study with cross-linguistic implications. Proceedings of the International Conference on Speech Prosody, 2002, Aix-en-Provence, pp. 319-322.

Ghini, M., 1993. Phi-formation in Italian: a new proposal. In: Dyck, C. (Ed.), Toronto Working Papers in Linguistics 12. Special Issue in Complexity in Phonological Representations, pp. 41-78.

Golston, C., Riad, T., 2000. The phonology of Classical Greek meter. Linguistics 38, 99-167.

Gussenhoven, C., 2004. The Phonology of Tone and Intonation. Cambridge University Press, Cambridge.

Hannahs, S.J., 1996. Phonological structure and soft mutation in Welsh. In: Kleinhenz, U. (Ed.), Interfaces in Phonology. Akademie Verlag, Berlin, pp. 46-59.

Hayes, B., Lahiri, A., 1991. Bengali intonational phonology. Natural Language and Linguistic Theory 9, 47-96.

Kaisse, E.M., 1977. On the syntactic environment of a phonological rule. In: Papers from the 13th Regional Meeting of the Chicago Linguistic Society, Chicago, IL, pp. 173-185.

Kaisse, E.M., 1985. Connected Speech. The Interaction of Syntax and Phonology. Academic Press, Orlando.

Kanerva, J.M., 1990. Focusing on phonological phrasing in Chicheŵa. In: Inkelas, S., Zec, D. (Eds.), The Phonology-Syntax Connection. The University of Chicago Press, Chicago, pp. 145-161.

Kisseberth, C.W., Abasheikh, M.I., 1974. Vowel length in Chi-Mwi:ni-a case study of the role of grammar in phonology. In: Bruck, A., Fox, R.A., La Galy, M.W. (Eds.), CLS 10, Papers from the Parasession on Natural Phonology, Chicago Linguistic Society, Chicago, pp. 193-209.

Kuijpers, C., Van Donselaar, W., 1997. The influence of rhythmic context on schwa epenthesis and schwa deletion in Dutch. Language and Speech 41, 87-108.

Liberman, M., Prince, A., 1977. On stress and linguistic rhythm. Linguistic Inquiry 8, 249-336.

Meinschaefer, J. Troncamento and the phonological phrase in Florentine Italian. Rivista di Linguistica, in press.

Napoli, D.J., Nespor, M., 1979. The syntax of word-initial consonant gemination in Italian. Language 55, 812-841.

Nespor, M., 1987. Vowel degemination and fast speech rules. Phonology Yearbook 4, 61-85.

Nespor, M., Vogel, I., 1986. Prosodic Phonology. Foris, Dordrecht.

Nespor, M., Vogel, I., 1989. On clashes and lapses. Phonology 6, 69-116.

Post, B., 1999. Restructured phonological phrases in French: evidence from clash resolution. Linguistics 37, 41-63.

Prieto, P., 2005. Syntactic and eurhythmic constraints on phrasing decisions in Catalan. Studia Linguistica 59, $194-222$.

Sandalo, F., Truckenbrodt, H., 2002. Some notes on phonological phrasing in Brazilian Portuguese. In: Csirmaz, A. Li, Z., Nevins, A., Vaysman, O., Wagner, M. (Eds.), Phonological Answers (and their Corresponding Questions), MIT Working Papers in Linguistics 42. MIT, Cambridge, MA, pp. 285-310.

Selkirk, E., 1974. French liaison and the X' notation. Linguistic Inquiry 5, 573-590.

Selkirk, E., 1986. On derived domains in sentence phonology. Phonology Yearbook 3, 371-405.

Selkirk, E., 1995. Sentence prosody: intonation, stress, and phrasing. In: Goldsmith, J.A. (Ed.), The Handbook of Phonological Theory. Blackwell, Oxford, pp. 550-569.

Selkirk, E., 2000. The interaction of constraints on prosodic phrasing. In: Horne, M. (Ed.), Prosody: Theory and Experiment. Kluwer, Dordrecht, pp. 231-261.

Selkirk, E., Shen, T., 1990. Prosodic domains in Shanghai Chinese. In: Inkelas, S., Zec, D. (Eds.), The Phonology-Syntax Connection. The University of Chicago Press, Chicago, pp. 313-337.

Thráinsson, H., 1994. Icelandic. In: König, E., Van der Auwera, J. (Eds.), The Germanic Languages. Routledge, London/ New York, pp. 142-189.

Truckenbrodt, H., 1995. Phonological phrases: their relation to syntax, focus, and prominence. Unpublished Ph.D. Dissertation. MIT, Cambridge, MA.

Truckenbrodt, H., 1999. On the relation between syntactic phrases and phonological phrases. Linguistic Inquiry 30 , 219-255. 